\title{
HUBUNGAN MOTIVASI KERJA PEGAWAI DENGAN PRODUKTIVITAS KERJA PEGAWAI KANTOR CAMAT TIGABINANGA KABUPATEN KARO
}

\author{
Oleh: \\ Novalina Kartika Sari Br Karo ${ }^{1)}$ \\ Marlon Sihombing 2) \\ Simson Ginting 3) \\ Universitas Darma Agung, Medan 1,2,3) \\ E-mail: \\ novalinakartikasari@gmail.com ${ }^{1)}$ \\ mrlnsihombing@gmail.com ${ }^{2)}$ \\ simson.sinisuka@gmail.com ${ }^{3)}$
}

\begin{abstract}
The theory used in the motivation variable is Herzberg's Motivation Theory in which motivation is divided into two, namely intrinsic and extrinsic motivation, then Maslow's Hierarchy of Needs Theory. One of the data collection techniques used in this research is through questionnaires and literature review of the object under study. From the results of hypothesis testing with a simple correlation (bivariate) that has been done, it shows that: There is a strong and real positive relationship between Employee Work Motivation (X) and Work Productivity (Y). This shows that the higher the level of work motivation, the better the performance will be. The partial correlation hypothesis testing shows that: There is a positive and real relationship between Work Motivation $(X)$ and Work Productivity $(Y)$, which indicates that the higher the level of Work Motivation, the better the productivity. The correlation value between $X$ and $Y$ is 0.714 , indicating that there is a close relationship between Work Motivation and Work Productivity. Hypothesis testing to see the relationship between the level of motivation and productivity is tested simultaneously. The test results show that there is a close and real relationship between the level of work motivation and work productivity, which is equal to 0.714
\end{abstract}

Keywords: Motivation, Productivity, Service, Public, Emploees

\begin{abstract}
ABSTRAK
Teori yang dipakai dalam variabel motivasi adalah Teori Motivasi Herzberg dimana motivasi itu terbagi dua yaitu motivasi intrinsik dan ekstrinsik, kemudian Teori Hierarki Kebutuhan dari Maslow. Teknik Pengumpulan Data yang dalam penelitian ini adalah salah satunya melalui questioner dan kajian kepustakaan terhadap objek yang diteliti. Dari hasil pengujian hipotesis dengan korelasi sederhana (bivariate) yang telah dilakukan menunjukkan bahwa: Ada hubungan positif yang erat dan nyata antara Motivasi Kerja Pegawai (X) dengan Produktivitas Kerja (Y). Hal tersebut menunjukkan bahwa semakin tinggi tingkat motivasi kerja, maka kinerja juga akan semakin baik. Pengujian hipotesis hubungan korelasi parsial menunjukkan bahwa: Terdapat hubungan yang positif dan nyata antara Motivasi Kerja (X) dengan Produktivitas Kerja (Y), yang menunjukkan semakin tinggi tingkat Motivasi Kerja, maka Produktivitas akan semakin baik. Nilai korelasi antara X dan Y adalah sebesar 0,714, menunjukkan bahwa ada hubungan yang erat antara Motivasi Kerja dengan Produktivitas Kerja. Pengujian hipotesis untuk melihat hubungan antara tingkat Motivasi dan Produktivitas yang dilakukan uji secara simultan. Hasil pengujian menunjukkan bahwa terdapat hubungan yang erat dan nyata antara tingkat motivasi kerja dan produktivitas kerja, yaitu sebesar 0,714.

Kata Kunci : Motivasi, Produktivitas, Pelayanan, Publik, Pegawai
\end{abstract}




\section{PENDAHULUAN}

Proses kegiatan pembangunan tidak pernah terlepas dari konsep produktivitas kerja karena produktivitas kerja sangat berkaitan dengan efektifitas dan efisiensi organisasi. Lebih lanjut dalam suatu organisasi, baik itu perusahaan swasta ataupun instansi Pemerintah, produktivitas kerja menjadi suatu hal yang patut diperhatikan dalam rangka pencapaian tujuan organisasi tersebut. Produktivitas kerja akan memperkuat posisi organisasi dalam berkompetisi baik dalam bidang pelayanan jasa maupun menghasilkan barang. Produktivitas dalam organisasi ditentukan oleh sumber daya manusia yang ada didalam organisasi tersebut.

Menurut Undang-Undang No 25 tahun 2009 tentang pelayanan publik yang merupakan kegiatan dalam pemenuhan kebutuhan pelayanan sesuai dengan peraturan perundang-undangan bagi setiap warega Negara dan penduduk atas barang dan atau pelayanan administrasi yang disediakan oleh penyelenggara pelayanan publik.

Dalam rangka pelayanan publik seperti yang tercantum pada abstraksi UU No. 5 Tahun 2014 tersebut maka seorang ASN harus mempunyai skala prioritas dalam bekerja dalam rangka pencapaian produktivitas agar tujuan organisasi yang telah ditetapkan dapat terwujud. Hadari Nawawi mendefenisikan produktifitas kerja sebagai suatu perbandingan antara hasil yang didapat dengan jumlah sumber yang digunakan. (Hadari, 1990:97) Produktifitas kerja sebagai suatu perbandingan antara hasil yang didapat dengan jumlah sumber yang digunakan. Sedangkan (Sinungan, 1997:12) menyebutkan produktivitas kerja merupakan suatu pengutaraan cara pemanfaatan secara baik terhadap sumber sumber dalam memproduksi barang. Defenisi produktivitas lebih lanjut
(Mulyono, 1993:27) adalah sebagai berikut : "Produktivitas hendaknya tidak hanya mengacu pada proses produksi fisik yang mentransformasikan berbagai masukan menjadi output, tetapi juga turut memperhatikan faktor-faktor yang mempengaruhi proses pencapaian produksi itu sendiri".

Motivasi merupakan salah satu variabel penting yang tidak bisa diabaikan dalam meningkatkan produktivitas dalam suatu organisasi baik organisasi Pemerintahan maupun swasta. Motivasi diharapkan dapat memberikan kontribusi untuk organisasi dalam proses untuk mencapai tujuan dari organisasi tersebut. Motivasi dapat diberikan dengan berbagai cara diantaranya adalah paksaan atau hukuman, imbalan, penghargaan dan pujian. Motivasi yang diberikan kepada pegawai dapat menciptakan pegawai memperbaiki dan meningkatkan semangat dalam bekerja sehingga produktivitas kerja pun dapat meningkat.

Seiring dengan proses pembangunan yang sedang dan akan terus dilaksanakan di Indonesia, maka diperlukan unsur motivasi yang tidak kalah pentingnya. Dalam suatu organisasi sangat perlu memperhatikan motivasi pegawai yang bekerja di dalamnya.

Dalam suatu organisasi, tenaga kerja atau sumber daya manusia sebagai motor penggerak merupakan asset yang sangat penting dan harus terpelihara dengan baik. Apabila tercipta produktifitas yang meningkat, maka sumber daya atau tenaga kerja dalam suatu organisasi harus memiliki semangat kerja yang tinggi. Pegawai yang bekerja dengan semangat akan menghasilkan pekerjaan yang maksimal karena pegawai akan terpacu untuk menghasilkan loyalitas dan semangat yang tinggi dalam tanggungjawab terhadap suatu pekerjaan. 


\section{TINJAUAN PUSTAKA}

Motivasi Herzberg

1. Motivasi Intrinsik

Motivasi intrnsik merupakan motivasi yang timbul dari diri seseorang, tidak perlu adanya rangsangan dari luar. Dari dalam diri seseorang sudah ada dorongan yang menimbulkan mereka untuk melakukan sesuatu. Motivasi Intrinsik lebih dikenal sebagai faktor motivasional. Yang tergolong sebagai faktor motivasional menurut Herzberg yang dikutip oleh Luthans (1992 : 160 ) , antara lain ialah :

a. Achievement (Keberhasilan)

Prestasi seorang pegawai bisa dilihat dari keberhasilannya dalam menyelesaikan tugas yang diberikan pimpinan kepadanya dengan baik.

b. Recognition (pengakuan/penghargaan)

Pimpinan memberi penghargaan terhadap keberhasilan pegawainya. Dalam hal ini terdapat beberapa cara yang dapat dilakukan yaitu:

a) Pernyataan keberhasilan secara langsung ditempat pekerjaannya.

b) Surat penghargaan.

c) Memberi hadiah seperti uang tunai.

d) Memberikan medali.

e) Memberikan kenaikan gaji (promosi)

c. Work it self (Pekerjaan itu sendiri)

Suatu usaha yang nyata dan meyakinkan dari pimpinan, sehingga membuat bawahan mengerti arti pentingnya pekerjaan yang dilakukan dan melakukan usaha untuk menghindar dari kebosanan serta mengusahakan agar semua bawahan tepat dalam menyelesaikan pekerjaannya.

d. Responsibility (Tanggung jawab)

Penerapan prinsip partisipasi dalam perencanaan dan pelaksanaan pekerjaan yang dilakukan sepenuhnya oleh bawahan.

e. Advencement (Pengembangan)

Faktor pengembangan berfungsi sebagai motivator, pemimpin dapat mengawali dengan melatih bawahannya untuk pekerjaan yang lebih bertanggung jawab. Kemudian pemimpin memberikan penilaian dan rekomendasi tentang bawahan yang berprestasi dan layak untuk dilakukan pengembangan seperti promosi jabatannya atau diutus untuk mengikuti pendidikan atau pelatihan lanjutan.

2. Motivasi Ekstrinsik

Motivasi ekstrinsik adalah motivasi yang timbul karena adanya pengaruh dari luar individu, dapat berupa suruhan, ajakan, atau paksaan dari orang lain yang mempengaruhi seseorang untuk melakukan suatu tindakan. Motivasi Ekstrinsik dikenal dengan hygiene factor. Yang tergolong sebagai hygiene faktor menurut Herzberg yang dikutip oleh Luthans (1992 : 160 ) adalah :

1. Policy and administration (Kebijakan dan administrasi)

Kantor personalia secara umum dibuat dalam bentuk tertulis dan biasanya yang dibuat dalam bentuk tertulis adalah baik, karena yang utama adalah bagaimana pelaksanaan dalam praktek. Pelaksanaan kebijakan dilakukan oleh manajer yang bersangkutan.

2. Quality supervisor (Supervisi)

Dengan technical supervisor yang menimbulkan kekecewaan dimaksud, adanya kekurang mampuan di pimpinan, bagaimana caranya pimpinan dapat bertanggungjawab dalam hal mensupervisi dari sisi teknis pekerjaan atau pimpinan tidak mempunyai kecakapan teknis dari yang diperlukan dari kedudukannya. Interpersonal relation menunjukkan hubungan perseorangan antara pegawai dengan pimpinannya, dimana kemungkinan pegawai merasa tidak dapat bergaul dengan pimpinannya.

Hierarki Teori Kebutuhan

Teori hierarki kebutuhan (hierarchy of needs) milik Abraham Maslow. Hal tersebut 
berkaitan dengan hipotesis bahwa dalam setiap diri manusia terdapat hierarki dari 5 (lima) kebutuhan yaitu:

1. Fisiologis, mencakup rasa haus dan lapar, seksual, berlindung, dan kebutuhan fisik lainnya,

2. Rasa aman, mencakup rasa ingin dilindungi dari bahaya emosional dan fisik.

3. Sosial, mencakup rasa penerimaan, kepemilikan, persahabatan dan kasih sayang.

4. Penghargaan, mencakup faktor - faktor penghargaan internal seperti pencapaian rasa hormat diri, serta otonomi, dan faktor-faktor penghargaan eksternal seperti pengakuan, perhatian dan status.

5. Aktualisasi diri, dorongan untuk menjadi seseorang berdasarkan kecakapannya, meliputi pencapaian potensi seseorang, pemenuhan diri sendiri dan pertumbuhan.

Kerangka Pemikiran dalam proposal penelitian ini adalah Produktifitas akan tercapai secara optimal jika pegawai mempunyai motivasi kerja yang baik. Dengan adanya pemberian motivasi secara tepat yang mendukung maka pegawai yang bekerja akan semakin semangat sehingga produktivitas pegawai akan semakin baik dan tujuan dari suatu organisasi akan tercapai dengan efektif dan efisien.
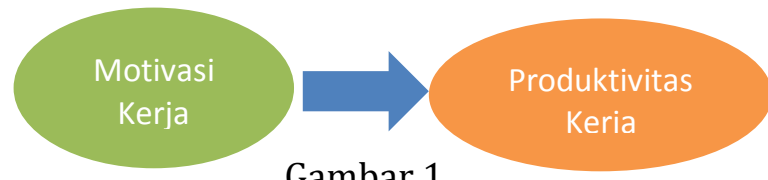

Gambar 1.

Hipotesis

Hipotesis merupakan jawaban sementara terhadap suatu masalah yang harus diuji kebenarannya secara empiris. Berdasar latar belakang dan rumusan masalah pada proposal penelitian ini penelitian maka hipotesis dalam penelitian ini dirumuskan bahwa :

1. $\mathrm{Ha}=$ jika diduga terdapat hubungan antara Motivasi Kerja dan Produktivitas Kerja
Pegawai Kantor Camat Tigabinanga Kabupaten Karo, semakin baik motivasi yang ada pada diri pegawai, dalam hal ini pegawai Kantor Camat Tigabinanga Kabupaten Karo, maka semakin tinggi tingkat produktivitas yang dihasilkan oleh Pegawai Kantor Camat Tigabinanga Kabupaten Karo.

2. Ho = jika tidak terdapat hubungan antara Motivasi Kerja Pegawai dan Produktivitas Kerja Pegawai Kantor Camat Tigabinanga Kabupaten Karo.

\section{METODE PELAKSANAAN}

a. Perspektif Pendekatan Penelitian

Penelitian ini menggunakan metode penelitian Kuantitatif dengan jenis deskriptif (angka yang diinterpretasikan dengan bahasa atau kata-kata). Penelitian ini juga menggunakan tehnik survey karena penelitian ini mengambil sampel dari suatu populasi dan menggunakan kuesioner sebagai alat pengumpul data yang pokok. Dua variabel yang digunakan dalam penelitian ini adalah satu variabel independent (bebas) yaitu motivasi kerja pegawai Kantor Camat Tigabinanga Kabupaten Karo dan satu variable dependent (terikat) yaitu produktivitas kerja pegawai Kantor Camat Tigabinanga Kabupaten Karo Secara sistematis :

1. Variabel dependent $(\mathrm{Y})$ atau variabel yang dipengaruhi adalah : Produktivitas Kerja Pegawai Kantor Camat Tigabinanga Kabupaten Karo

2. Variabel independent (X) atau variabel yang mempengaruhi adalah Motivasi Kerja Pegawai Kantor Camat Tigabinanga Kabupaten Karo

Makna variabel dalam penelitian ini sebagai berikut :

1. Motivasi Kerja Pegawai Kantor Camat Tigabinanga Kabupaten Karo adalah suatu semangat ataupun kekuatan yang timbul dari dalam diri pegawai Kantor Camat 
Tigabinanga Kabupaten Karo yang secara sadar dilakukan untuk melaksanakan suatu kegiatan yang dapat menghasilkan suatu perubahan kearah kemajuan dalam mengatasi suatu masalah sehingga dapat berdaya guna dan berhasil guna bagi lingkungan sekitarnya.

2. Produktivitas Kerja Pegawai Kantor Camat Tigabinanga Kabupaten Karo adalah suatu kemampuan yang dimiliki oleh pegawai Kantor Camat Tiga Binaga Kabupaten Karo dalam menyelesaikan tugas ataupun pekerjaan sehingga dapat menghasilkan suatu produk yaitu barang maupun jasa dengan menggunakan satuan waktu tertentu. Dalam hal ini mengukur produktivitas kerja pegawai dilakukan pada setiap variabel dan dimensi dengan menggunakan ukuran yang tertera pada kuesioner b. Operasionalisasi Variabel

mengklasifikasikan operasionalisasi variabel tersebut dalam bentuk tabel dengan tujuan untuk memudahkan membaca dan mengetahui operasionalisasi variabel :

Tabel 1. Operasionalisasi Variabel

\begin{tabular}{|l|l|l|}
\hline $\begin{array}{l}\text { Variabe } \\
\text { 1 }\end{array}$ & Indikator & Dimensi \\
\hline $\begin{array}{l}\text { Motivas } \\
\text { i Kerja }\end{array}$ & $\begin{array}{l}\text { 1. Tanggung } \\
\text { Jawab }\end{array}$ & $\begin{array}{l}\text { Kewajiban } \\
\text { melaksanakan } \\
\text { peranan sesuai } \\
\text { ketentuan. } \\
\text { Melaksanakan dan } \\
\end{array}$ \\
& 2. Tingkat Usaha & $\begin{array}{l}\text { Menyelesaikan } \\
\text { kewajuban dengan } \\
\text { penuh semangat } \\
\text { dan penuh } \\
\text { kekrelaan } \\
\text { (kegigihan). } \\
\text { Penghargaan yang } \\
\text { diberikan dan } \\
\text { hukuman sesuai } \\
\text { bidang dan tingkat } \\
\text { pelaksanaan } \\
\text { kewajiban masing- } \\
\text { masing pegawai }\end{array}$ \\
\hline
\end{tabular}

\begin{tabular}{|l|l|l|}
\hline $\begin{array}{l}\text { Produk } \\
\text { tivitas } \\
\text { Kerja }\end{array}$ & 1. Kualitas & Kriteria Pekerjaan. \\
& & Kesesuaian \\
& Pekerjaan. \\
& 2. Kuantitas & Tingkat Kesalahan \\
& Pekerjaan \\
& Pekerjaan & Tingkat \\
& & Penyelesaian \\
& & Pekerjaan. \\
& & Tingkat Penentuan \\
& & Jumlah Pekerjaan. \\
& & Tingkat \\
& & Penyelesaian \\
& & Target Tepat \\
& & Waktu. \\
\hline
\end{tabular}

c. Instrumen Penelitian

Dalam proses pengumpulan data, instrument atau alat yang akan dipakai adalah kuesioner yang berisi pertanyaanpertanyaan yang akan dijawab oleh responden yang terdiri dari pegawai Kantor Camat Tigabinanga Kabupaten Karo. Keseluruhan jawaban yang diberikan tersebut diidentifikasikan kedalam 5 (lima) kategori yaitu sangat setuju, setuju, raguragu, tidak setuju dan sangat tidak setuju. Pemberian skor mengacu pada skala Likert yang diklasifikasikan dalam 5 (lima) tingkatan dan diberi skor antara 1 (satu) sampai 5 (lima).

d. Uji Validitas Instrumen

Jika peneliti menggunakan kuesioner dalam pengumpulan data penelitian , maka itemitem yang disusun pada kuesioner tersebut merupakan alat test yang harus mengukur apa yang menjadi tujuan penelitian. Menggunakan SPSS.

e. Uji Reliabilitas Instrumen

Reliabilitas artinya adalah tingkat kepercayaan hasil suatu pengukuran. Pengukuran yang memiliki reliabilitas yang tinggi, yaitu pengukuran yang dapat memberikan hasil yang terpercaya (reliable). Reliabilitas adalah ciri atau karakter utama instrument pengukuran yang baik.

\section{f. Unit Analisis}

Unit analisis dalam penelitian ini adalah organisasi, yaitu Kantor Camat Tigabinanga 
Kabupaten Karo. Unit analisis yang selanjutnya adalah individu, yaitu pegawai Kantor Camat Tigabinanga Kabupaten Karo.Populasi dalam penelitian ini adalah seluruh pegawai Kantor Camat Tigabinanga Kabupaten Karo yang tercantum dalam bagan struktur organisasi pada Kantor Camat Tigabinanga Kabupaten Karo, terdiri dari 27 (dua puluh tujuh ) orang. Terdiri dari 23 orang ASN dan 4 orang tenaga honorer. Sampel adalah bagian kecil dari himpunan unit observasi yang memberikan keterangan atau data yang diperlukan . Sampel dalam penelitian ini berjumlah 27 0rang.

g. Metode Pengumpulan Data

Dialog langsung dengan informan secara mendalam mengenai permasalahan yang sedang diteliti. Teknik wawancara yang dilakukan adalah dengan cara melakukan tanya jawab dengan pegawai Kantor Camat Tigabinanga Kabupaten Karo. Observasi, dilakukan dengan mengadakan pengamatan secara langsung pada unit analisis organisasi Kantor Camat Tigabinanga Kabupaten Karo.

h. Teknik Analisa Data

Metode yang digunakan dalam analisis data pada penelitian ini adalah metode analisis korelasi (correlation analysis). Analisis korelasi dilakukan untuk melihat ada tidaknya hubungan antara variabel satu dengan variabel lainnya. Dalam penelitian ini akan dilihat Hubungan Motivasi Kerja Pegawai dengan Produktivitas Kerja Pegawai Kantor Camat Tigabinanga Kabupaten Karo.

\section{HASIL dan PEMBAHASAN}

Pada penelitian ini dilakukan survey terhadap 27 orang responden yang diperoleh dengan Stratified Random Sampling sebagaimana yang telah dijelaskan pada bab sebelumnya.

Deskripsi data hasil survey terhadap 27 orang responden yang dijadikan sampel dalam penelitian untuk melihat hubungan Motivasi Kerja Pegawai dengan Produktivitas Kerja Pagawai adalah sebagai berikut :

Pada penelitian ini terdiri dari dua variabel, yaitu satu variabel bebas (independent) dan satu variabel terikat (dependent). Adapun variabel bebas $(\mathrm{X})$ pada penelitian ini adalah Motivasi Kerja Pegawai sedangkan Variabel Terikatnya(Y). adalah Produktivitas Pegawai.

Untuk mengukur variabel Motivasi Kerja Pegawai diberikan 6 item pertanyaan/pernyataan yang terbagi atas tiga dimensi meliputi : tanggung jawab, tingkat usaha serta reward dan punishment. Masing-masing dimensi terdiri atas beberapa item pertanyaan/pernyataan yang memiliki jawaban berskala ordinal dengan skoring menggunakan skala Likert yaitu dari 1 sampai 5.

Tabel 2. Tanggapan Responden atas Instrumen Motivasi Kerja Pegawai (X)

\begin{tabular}{|c|c|c|c|c|c|c|c|c|c|c|c|c|}
\hline No. & \multicolumn{2}{|c|}{$\begin{array}{l}\text { Sangat } \\
\text { Setuju }\end{array}$} & \multicolumn{2}{|c|}{ Setuju } & \multicolumn{2}{|c|}{ Ragu } & \multicolumn{2}{|c|}{$\begin{array}{l}\text { Tidak } \\
\text { Setuju }\end{array}$} & \multicolumn{2}{|c|}{$\begin{array}{l}\text { Sangat } \\
\text { Tidak } \\
\text { Setuju }\end{array}$} & \multicolumn{2}{|c|}{ Total } \\
\hline & $\mathrm{F}$ & $\%$ & $\mathrm{~F}$ & $\%$ & $\mathrm{~F}$ & $\%$ & $\mathrm{~F}$ & $\%$ & $\mathrm{~F}$ & $\%$ & $\mathrm{~F}$ & $\%$ \\
\hline 1 & 5 & 3 & $\begin{array}{l}2 \\
3\end{array}$ & $\begin{array}{l}8 \\
6\end{array}$ & 3 & $\begin{array}{l}1 \\
1\end{array}$ & 0 & 0 & 0 & 0 & $\begin{array}{l}2 \\
7\end{array}$ & $\begin{array}{l}10 \\
0\end{array}$ \\
\hline 2 & 0 & 0 & $\begin{array}{l}2 \\
2\end{array}$ & $\begin{array}{l}8 \\
1\end{array}$ & 5 & $\begin{array}{l}1 \\
9\end{array}$ & 0 & 0 & 0 & 0 & $\begin{array}{l}2 \\
7\end{array}$ & $\begin{array}{l}10 \\
0\end{array}$ \\
\hline 3 & 2 & 7 & $\begin{array}{l}2 \\
3\end{array}$ & $\begin{array}{l}8 \\
6\end{array}$ & 2 & 7 & 0 & 0 & 0 & 0 & $\begin{array}{l}2 \\
7\end{array}$ & $\begin{array}{l}10 \\
0\end{array}$ \\
\hline 4 & 3 & $\begin{array}{l}1 \\
1\end{array}$ & $\begin{array}{l}1 \\
9\end{array}$ & $\begin{array}{l}7 \\
0\end{array}$ & 5 & $\begin{array}{l}1 \\
9\end{array}$ & 0 & 0 & 0 & 0 & $\begin{array}{l}2 \\
7\end{array}$ & $\begin{array}{l}10 \\
0\end{array}$ \\
\hline 5 & 2 & 7 & $\begin{array}{l}2 \\
5\end{array}$ & $\begin{array}{l}9 \\
3\end{array}$ & 0 & 0 & 0 & 0 & 0 & 0 & $\begin{array}{l}2 \\
7\end{array}$ & $\begin{array}{l}10 \\
0\end{array}$ \\
\hline 6 & 8 & $\begin{array}{l}3 \\
0\end{array}$ & $\begin{array}{l}1 \\
7\end{array}$ & $\begin{array}{l}6 \\
3\end{array}$ & 2 & 7 & 0 & 0 & 0 & 0 & $\begin{array}{l}2 \\
7\end{array}$ & $\begin{array}{l}10 \\
0\end{array}$ \\
\hline
\end{tabular}

Berdasarkan datadiatas dapat diinterpretasikan bahwa secara umum jawaban responden untuk dimensi tingkat usaha( dengan item melaksanakan dan menyelesaikan suatu kewajiban dengan penuh semangat dan penuh kerelaan) dalam katagori jawaban atau skor sangat setuju mempunyai nilai paling tinggi yaitu sebesar (100\%) yang menjawab setuju terhadap beberapa pernyataan pada item tersebut. Pada hampir semua item menunjukkan 
bahwa jawaban setuju (skor 4) memiliki persentase yang paling tinggi. Hal ini menunjukkan bahwa jawaban responden relative homogen dengan sebagian besar menjawab setuju. Hal ini dapat diartikan bahwa tingkat motivasi kerja pegawai pada Kantor Camat Tigabinanga relatif baik.

Tabel 3. Tanggapan Responden atas Instrumen Produktifitas Kerja Pegawai (X)

\begin{tabular}{|l|l|l|l|l|l|l|l|l|l|l|l|l|l|}
\hline No & \multicolumn{2}{|c|}{$\begin{array}{c}\text { Sangat } \\
\text { Setuju }\end{array}$} & \multicolumn{2}{|c|}{ Setuju } & \multicolumn{2}{|c|}{ Ragu } & \multicolumn{2}{|c|}{$\begin{array}{c}\text { Tidak } \\
\text { Setuju }\end{array}$} & $\begin{array}{c}\text { Sangat } \\
\text { Tidak } \\
\text { Setuju }\end{array}$ & \multicolumn{3}{|c|}{ Total } \\
\hline & $\mathrm{F}$ & $\%$ & $\mathrm{~F}$ & $\%$ & $\mathrm{~F}$ & $\%$ & $\mathrm{~F}$ & $\%$ & $\mathrm{~F}$ & $\%$ & $\mathrm{~F}$ & $\%$ \\
\hline 1 & 2 & 7 & 23 & 86 & 2 & 7 & 0 & 0 & 0 & 0 & 27 & 100 \\
\hline 2 & 27 & 100 & 0 & 0 & 0 & 0 & 0 & 0 & 0 & 0 & 27 & 100 \\
\hline 3 & 3 & 11 & 19 & 70 & 5 & 3 & 0 & 0 & 0 & 0 & 27 & 100 \\
\hline 4 & 2 & 7 & 16 & 60 & 9 & 33 & 0 & 0 & 0 & 0 & 27 & 100 \\
\hline 5 & 5 & 3 & 18 & 67 & 4 & 15 & 0 & 0 & 0 & 0 & 27 & 100 \\
\hline 6 & 3 & 11 & 23 & 86 & 1 & 3 & 0 & 0 & 0 & 0 & 27 & 100 \\
\hline
\end{tabular}

Dalam penelitian ini, pengujian validitas data dilakukan menggunakan SPPS 22 dengan membandingkan pada kolom corrected item total correlation. Dengan ketentuan nilai korelasi diatas 0,468 (nilai $\mathrm{f}$ tabel) dengan tingkat signifikansi 5\% dari nilai setiap butir pertanyaan pada kolom corrected item total correlation, maka pertanyaan tersebut valid.

Tabel 4. Ringkasan Tabulasi Uji Validitas Motivasi Kerja Pegawai (X)

\begin{tabular}{|c|c|c|c|}
\hline pertanyaan & $\begin{array}{c}\text { Koefisien } \\
\text { korelasi }\end{array}$ & $\begin{array}{c}\text { F } \\
\text { tabel }\end{array}$ & keterangan \\
\hline Item1 & $\mathbf{0 , 4 7 2}$ & 0,468 & Valid \\
Item2 & $\mathbf{0 , 5 0 4}$ & 0,468 & Valid \\
Item3 & $\mathbf{0 , 5 9 0}$ & 0,468 & Valid \\
Item4 & $\mathbf{0 , 8 3 6}$ & 0,468 & Valid \\
Item5 & $\mathbf{0 , 7 9 3}$ & 0,468 & Valid \\
Item6 & $\mathbf{0 , 6 0 8}$ & 0,468 & Valid \\
\hline
\end{tabular}

Dari hasil analisis secara deskriptif pada masing-masing variabel baik variabel Motivasi Kerja maupun Variabel Produktivitas Kerja Pegawai pada Kantor Camat Tigabinanga Kabupaten Karo adalah menunjukkan tingkatan yang relative baik. Hal ini ditandai dengan skor rata-rata tertinggi pada masing-masing dimensi bernilai 4 .

Dari hasil pengujian hipotesis dengan korelasi sederhana (bivariate)yang telah dilakukan menunjukkan bahwa:

Ada hubungan yang positif dan nyata antara Motivasi Kerja(X) dengan Produktivitas Kerja (Y). Hal ini menunjukkan bahwa semakin tinggi tingkat Motivasi Kerja, maka Produktivitas Kerja juga akan semakin baik. Nilai korelasi antara X dan Y adalah sebesar 0,714 . Hal ini menunjukkan bahwa ada hubungan yang erat antaraMotivasi Kerja dengan Produktivitas Kerja.

Pengujian hipotesis dilakukan untuk melihat hubungan antara tingkat Motivasi Kerja dan Produktivitas Kerja yang dilakukan uji secara simultan. Dari hasil pengujian menunjukkan bahwa terdapat Hubungan yang Erat dan Nyata antara tingkat motivasi Kerja denganProduktivitas Kerja, yaitu sebesar 0,714.

\section{SIMPULAN}

Dari hasil analisis dan pembahasan yang telah dilakukan baik secara deskriptif maupun secara statistik dapat diambil beberapa kesimpulan sebagai berikut :

1. Berdasarkan hasil analisis secara deskriptif pada masing-masing variabel, baik variabel Motivasi Kerja (X) maupun Variabel Produktivitas Kerja (Y) pada Kantor Camat Tigabinanga Kabupaten Karo adalah menunjukkan terdapat hubungan yang erat (nilai korelasi $0,70-0,89$ ) dan menunjukkan tingkatan yang baik.

a. Berdasarkan analisis korelasi sederhana (Bivariat) untuk melihat hubungan antara dua variabel menunjukkan bahwa :

b. Terdapat hubungan yang positif yang nyata antara Motivasi Kerja (X) dengan Produktivitas Kerja (Y) pada Kantor Camat Tigabinanga Kabupaten Karo.

c. Dari analisis korelasi secara parsial menunjukkan bahwa :

a. Ada hubungan positif dan nyata antara variabel Motivasi Kerja dengan Produktivitas Kerja pada Kantor Camat Tigabinanga Kabupaten Karo. Hal ini 
menunjukkan bahwa semakin tinggi motivasi bekerja, maka produktivitas Kerja akan semakin baik atau meningkat.

b. Hasil pengujian secara simultan menunjukkan bahwa Ada hubungan positif yang nyata antara Motivasi Kerja (X) dengan Produktivitas Kerja (Y). Hal ini menunjukkan bahwa semakin tinggi tingkat Motivasi Kerja, maka Produktivitas Kerja juga akan semakin baik.

c. Berdasarkan hasil pengujian hipotesis hubungan korelasi parsial menunjukkan bahwa: Ada hubungan yang positif dan nyata antara Motivasi Kerja(X) dengan Produktivitas Kerja (Y). Hal ini menunjukkan bahwa semakin baik tingkat Motivasi Kerja, maka Produktivitas kerja juga akan semakin baik.

\section{DAFTAR PUSTAKA}

Ananto, S., Rahyuda, I. K., \& Priartrini, P. S. (2016). Pengaruh Motivasi Terhadap Kepuasan Kerja dan Intensi Keluar Pada Asisten Kursus Metode Kumon di Bali dan Lombok. E-Jurnal Ekonomi Dan Bisnis Universitas Udayana, 9, 3057-3086.

Andjarwati, T. (2015). Motivasi dari Sudut Pandang Teori Hirarki Kebutuhan Maslow, Teori Dua Faktor Herzberg, Tero X Y Mc Gregor, dan Teori Motivasi Prestasi Mc Clelland. Jurnal Ilmu Ekonomi \& Manajemen, 1(1), 45--54.

Angraeni, Baharuddin, \& Mattalatta. (2019). Jurnal Mirai Management Jurnal Mirai Management. Jurnal Mirai Managemnt, 4(2), 122-136.

Kasim, F., \& Ginting, A. (2019). Faktor Determinan Yang Berhubungan Dengan Motivasi Kerja Pegawai Di Puskesmas Juhar Kecamatan Juhar Kabupaten Karo. Jurnal
Penelitian Kesmasy, 2(1), 75-83.

Lolitha, Y., Vanhurk, H., Ningsih, S., \& Agung, U. D. (n.d.). PENITIPAN ANAK IRUKA JALAN JAMIN GINTING KM 8,5 MEDAN Oleh : 5, 31-43.

Pramono, J. (2007). Pengaruh Faktor Higine Dan Pemuas Pada Motivasi Dan Kinerja: Uji Terhadap Teori Herzberg. Jurnal Fakultas Ekonomi : OPTIMAL, 1(1), 1-12.

Setiadi, W. (2018). ANALISIS PENGARUH KUALITAS PELAYANAN JASA GADAI TERHADAP KEPUASAN NASABAH PADA PT. PEGADAIAN (PERSERO) CP GAHARU MEDAN. 227-249.

Shanti, N. C. (2013). Pengaruh Motivasi dan Lingkungan Fisik Tempat Kerja Terhadap Prestasi Kerja Pegawai Pada Dinas Cipta Karya dan Tata Kota Samarinda. Jurnal Administrasi Reform, 1(1), 131-151.

Surwanti, A. (2011). MOTIVASI KERJA, KEPUASAN KERJA, DAN KINERJA Arni Surwanti Universitas Muhammadiyah Yogyakarta. 1, 88-97.

Suwarto, F. (2017). Analisis variabelvariabel yang mempengaruhi motivasi kerja pada koperasi persatuan pedagang kaki lima yogyakarta (kppkly). Jurnal Manajemen, 21(2), 255-269 